\title{
PERAN EMPATI DAN SELF-EFFICACY GURU TK TERHADAP GAYA PENGATURAN KELAS DALAM KONTEKS UNJUSTIFIED AGGRESSION
}

\author{
Carolyne Sutradjaja ${ }^{1}$, Riana Sahrani ${ }^{2}$, dan Fransisca Iriani R. Dewi ${ }^{\mathbf{3}}$ \\ ${ }^{1}$ Program Studi Psikologi Profesi Jenjang Magister, Universitas Tarumanagara, Jakarta \\ Email: carolyne.717162024@stu.untar.ac.id \\ ${ }^{2}$ Fakultas Psikologi, Universitas Tarumanagara, Jakarta \\ Email: riana1123@gmail.com \\ ${ }^{3}$ Fakultas Psikologi, Universitas Tarumanagara, Jakarta \\ Email: fransiscar@fpsi.untar.ac.id
}

\begin{abstract}
ABSTRAK
Penelitian sebelumnya mengaitkan empati dan self-efficacy dengan kemungkinan guru TK merespon situasi bullying. Akan tetapi belum ada penelitian yang mengaitkan empati dan self-efficacy dengan actual behaviour guru TK di dalam kelas. Maka penelitian ini dilakukan untuk melihat peran empati dan self-efficacy terhadap gaya pengaturan kelas guru TK dalam konteks unjustified aggression. Hal ini dipertimbangkan karena gaya pengaturan kelas kerap dikaitkan dengan perilaku konkrit yang diterapkan oleh guru di dalam kelas. Partisipan dalam penelitian ini adalah 124 guru TK dan preschool, teknik pengambilan sampel menggunakan non-probability dan snowball sampling. Analisis data dilakukan menggunakan regresi berganda (multiple regression) dan didapatkan bahwa tingkat empati dan self-efficacy guru TK memiliki peran signifikan terhadap gaya pengaturan kelas sebesar $17.5 \%(\mathrm{~F}$ $=14.045, \mathrm{p}=0.00<0.05)$. Hal ini mengindikasikan bahwa tingkat empati dan self-efficacy guru TK dapat memprediksi bagaimana mereka mengelola kelas, yang terlihat dalam perilaku saat mereka menetapkan kontrol serta membangun interaksi dengan siswa. Analisis lebih lanjut dilakukan untuk melihat peran empati dan self-efficacy terhadap masing-masing dimensi dalam gaya pengaturan kelas, yaitu kontrol dan keterlibatan guru. Dari analisis tersebut ditemukan bahwa konstruk empati memiliki peran signifikan terhadap keterlibatan guru, sedangkan konstruk self-efficacy memiliki peran signifikan terhadap disiplin.
\end{abstract}

Kata kunci: unjustified aggression, self-efficacy, empati, gaya pengaturan kelas

\begin{abstract}
Previous research linked empathy and self-efficacy to the possibility of kindergarten teachers responding to bullying situations. However, there are no studies that relate empathy and self-efficacy with the actual kindergarten teacher behaviour in the classroom. Therefore this study was conducted to examine the role of empathy and self-efficacy towards the classroom management style of kindergarten teachers in the context of unjustified aggression. This is considered because the style of classroom management is often associated with concrete behaviour that is applied by the teacher in the classroom. Participants were 124 kindergarten and preschool teachers, the sampling technique was non-probability and snowball sampling. Data analysis was performed using multiple regression (multiple regression) and it was found that the level of empathy and self-efficacy of kindergarten teachers had a significant role in the style of classroom management by $17.5 \%(F=14,045, p=0.00<0.05)$. This indicates that the level of empathy and self-efficacy of kindergarten teachers can predict how they manage the classroom, which is seen in behavior when they establish controls and build interactions with students. Further analysis was carried out to see the role of empathy and self-efficacy towards each dimension in the style of classroom management, namely teacher control and involvement. From the analysis it was found that the construct of empathy has a significant role on teacher involvement, while the construct of self-efficacy has a significant role on discipline.
\end{abstract}

Keywords: unjustified aggression, self-efficacy, empathy, classroom management style 


\section{PENDAHULUAN}

\section{Latar Belakang}

Perilaku agresif pada anak usia dini oleh Shaw, Gilliom dan Giovannelli (dalam Reebye, 2005) didefinisikan sebagai perilaku yang ditujukan secara spesifik pada orang lain dengan intensi untuk menyakiti atau menakuti. Berdasarkan prinsip universalitas, maka anak-anak dari berbagai kultur seharusnya memperlihatkan perilaku agresif dalam derajat tertentu sebagai bagian dari proses perkembangannya (Reebye, 2005). Hartup (dalam Cumming, Ianotti \& Waxler, 1989) menemukan bahwa anak usia dini lebih sering menampilkan perilaku agresif daripada anak yang lebih tua. Namun stabilitas perilaku agresif pada anak usia dini diketahui memiliki tingkat stabilitas yang rendah.

Memasuki usia taman kanak-kanak anak pertama kali secara formal menjadi anggota dari kelompok bermain yang lebih stabil dan menjalani aktivitas bersama yang lebih terorganisir (Vlachou, Andreou, Botsoglou \& Didaskalou, 2011). Oleh karena itu taman kanak-kanak dapat menjadi lingkup pertama di luar lingkungan rumah di mana anak-anak dapat menemui kesulitan dalam interaksi sosial dengan teman sebaya dan dapat dideteksi oleh orang dewasa maupun profesional (Vlachou, Andreou, Botsoglou \& Didaskalou, 2011). Sayangnya perilaku agresif pada anak usia dini kerap diabaikan atau disepelekan, dan dinilai sebagai bagian dari proses perkembangan dan pendewasaan (Reebye, 2005). Namun telah banyak penelitian membuktikan bahwa perilaku agresif pada anak usia dini yang tidak ditangani dengan tepat dapat menjadi prediktor penting bagi berkembangnya perilaku agresif di kemudian hari (Reebye, 2005; Loeber \& Hay, 1997; Ireland, Birch, \& Ireland, 2018, Eriksson, Lindbrg, Flygare, \& Daneback, dalam Kirves \& Sajaniemi, 2012)

Istilah agresivitas dapat meliputi berbagai jenis tindakan, termasuk agresi verbal, bullying, perkelahian fisik, dan berbagai bentuk kekerasan lainnya (Loeber \& Hay, 1997). Studi mengenai perilaku agresif pada anak usia dini kerap menggunakan istilah "bullying", "aggression", dan "victimization" (Monks, Ruiz \& Val, 2002). Meski ketiga konsep ini saling berhubungan namun tidak identik. Fitur yang membedakan bullying dari perilaku agresif secara umum yakni adanya intensi (niat), repetisi (terjadi berulang kali), dan ketidakseimbangan perilaku sehingga korban mengalami kesulitan untuk melepaskan diri (Monks, Ruiz \& Val, 2002; Vlachou, Botsoglou \& Andreou, 2014). Monks, Ruiz dan Val (2002) pada akhirnya mengajukan konsep unjustified aggression sebagai konstruk yang dinilai lebih tepat untuk menjelaskan bullying pada anak usia dini, di mana memang karakteristik intensi, repetisi dan ketidakseimbangan kekuatan belum menjadi ciri menetap. Unjustified aggression didefinisikan saat seorang atau sekelompok anak dihina, dipukul, dikucilkan secara sosial, atau diancam oleh anak lain tanpa motif yang jelas (Monks, Ruiz ${ }^{\wedge}$ Val, 2002).

Minimnya pemahaman anak terhadap dampak dari perilaku agresif yang dilakukan menyebabkan peran guru TK menjadi krusial sebagai tokoh sentral di sekolah. Hasil wawancara dan observasi tidak terstruktur yang peneliti lakukan di beberapa taman kanak-kanak di Jakarta menggambarkan bahwa sebagian guru menilai perilaku agresif yang dilakukan oleh anak TK merupakan hal yang wajar dan merasa belum perlu menerapkan langkah khusus untuk menanggulanginya, serta berharap bahwa perilaku agresif siswa akan berkurang seiring dengan perkembangan usia mereka. Sementara sebagian lainnya menilai bahwa perilaku agresif siswa adalah hal serius yang perlu ditanggulangi sejak dini (komunikasi personal, TK X, Y dan Z, 27 Januari 2018). 
Berbagai studi pada anak-anak yang lebih tua menunjukkan bahwa minimnya respon guru terhadap bullying yang dilakukan siswa dipengaruhi oleh faktor kurangnya pengetahuan serta karakteristik personal yang dimiliki guru seperti empati dan self-efficacy (Yoon, 2004; Yoon \& Kerber, 2003; Lee 2016; Murphy, Tubritt \& Norman, 2018; Gregus, Rodriguez, Pastrana, Craig, McQuillin, \& Cavel, 2017). Sayangnya penelitian-penelitian tersebut hanya melihat peran empati dan self-efficacy terhadap intensi guru untuk merespon fenomena kekerasan yang terjadi. Yoon, Sulkowski, dan Bauman (2014) menyatakan bahwa intensi guru untuk merespon belum tentu sejalan dengan actual behavior-nya di dalam kelas. Untuk itu diperlukan penelitian selanjutnya, di mana respon guru lebih dipahami dalam konteks pengaturan kelas (Yoon \& Bauman, 2014).

Guru memiliki peran signifikan untuk menciptakan lingkungan belajar dan membudayakan iklim kelas yang baik, termasuk merespon kebutuhan siswa (Cooper, dalam Goroshit \& Hen, 2016). Untuk itu dibutuhkan kemampuan berempati bagi guru untuk dapat benar-benar menyadari tugas dan kewajibannya sebagai sosok yang harus mempertimbangkan kebutuhan pastoral siswa dan memberikan respon yang tepat (Murphy, Tubritt \& Norman, 2018). Demikian pula self-efficacy memiliki pengaruh yang kuat terhadap pilihan yang dibuat oleh guru, seberapa besar usaha yang akan ia lakukan, kegigihan ketekunan serta pencapaiannya saat menghadapi situasi yang sulit di dalam kelas (Britner \& Pajares, dalam Goroshit \& Hen, 2016).

Dengan demikian peneliti menyimpulkan bahwa pada dasarnya empati maupun self-efficacy guru memiliki kaitan dengan bagaimana cara guru berinteraksi dan memperlakukan siswanya. Cara guru berperilaku di dalam kelas dijelaskan oleh Sullivan, Cleary, dan Sullivan (dalam Murphy, Tubritt \& Norman, 2018) dapat dieskpresikan dalam bentuk classroom management behavior yang digunakan. Lebih jauh lagi hasil penelitian menunjukkan bahwa kelas yang dikelola dengan gaya selain authoritative akan lebih memunculkan budaya bullying.

Hal ini pada akhirnya merujuk kepada pentingnya telaah lebih lanjut mengenai apakah ada peran dari empati dan self-efficacy guru TK terhadap gaya pengaturan kelas dalam konteks unjustified aggression karena memiliki implikasi pada kepentingan untuk mengasah lebih lanjut potensi serta kompetensi guru TK.

\section{Rumusan Masalah}

Permasalahan yang akan dikaji dalam penelitian ini adalah apakah terdapat peran dari empati dan self-efficacy guru TK terhadap gaya pengaturan kelas dalam konteks unjustified aggression.

\section{METODE PENELITIAN}

Sampel dalam penelitian ini adalah 135 orang guru yang mengajar pada jenjang taman kanakkanak dan preschool di area Jakarta dengan rentang usia 19 hingga 52 tahun. Setelah dilakukan pemeriksaan terhadap data, tersaring hanya 124 partisipan yang dapat diikutsertakan dalam penelitian, karena data dari 11 partisipan bersifat outlier, sehingga tidak dapat diolah. Pemilihan sampel menggunakan metode non-probability dan teknik snowball sampling. Desain penelitian adalah quantitative non-experimental dan menggunakan uji regresi statistik untuk menjelaskan peran dari dua atau lebih variabel. Sedangkan pengambilan data dilakukan dengan metode crosssectional, di mana pengambilan data dilakukan hanya pada satu waktu tertentu saja.

Pengambilan data dilakukan sesuai perjanjian yang dilakukan saat peneliti menghubungi partisipan melalui aplikasi pesan ataupun email. Peneliti melakukan penyebaran kuesioner dengan menggunakan kuesioner fisik (hard copy) dan kuesioner online (aplikasi google form). 


\section{Pengukuran/Instrumen Penelitian}

Peneliti mengembangkan tiga alat ukur dalam penelitian ini yaitu: skala empati guru TK, skala self-efficacy guru TK, dan skala gaya pengaturan kelas guru TK. Uji validitas dalam penelitian ini adalah construct validity, diukur dengan menggunakan model pengukuran confirmatory factor analysis (CFA) pada program Lisrel. Sedangkan uji reliabilitas dilakukan dengan menggunakan teknik cronbach alpha (internal consistency) pada program spss 24.00.

Skala empati guru TK memiliki definisi konseptual kemampuan guru untuk dapat memahami perilaku ataupun pemikiran siswa, serta merasakan apa yang dirasakan oleh siswa. Definisi operasional dari variabel empati adalah semakin tinggi skor yang diperoleh pada skala ini menggambarkan semakin tinggi kemampuan guru berempati pada siswa. Dimensi empati kognitif memiliki contoh butir positif: Saya bisa memahami mengapa siswa berperilaku agresif terhadap temannya di usia yang begitu muda. Sedangkan contoh butir negatif: Sulit bagi saya memahami cara berpikir siswa. Dimensi empati afektif memiliki contoh butir positif: Penghayatan saya terhadap emosi yang dirasakan oleh siswa selalu tepat. Sedangkan contoh butir negatif adalah: Tidak mudah bagi saya menyesuaikan diri dengan perasaan siswa yang mendadak berubah.

Definisi konseptual dari variabel self-efficacy adalah penilaian guru akan kemampuan dirinya dalam melaksanakan tugas-tugas yang berkaitan dengan kontrol terhadap perilaku agresif yang dilakukan siswa TK di sekolah. Definisi operasional dari variabel self-efficacy adalah semakin tinggi skor yang ditunjukkan oleh skala ini menggambarkan semakin baik penilaian guru terhadap kemampuan dirinya. Contoh butir dalam penelitian ini adalah: Saya mampu menanamkan sikap-sikap sosial yang positif pada siswa saya, meskipun mereka masih kecil.

Definisi konseptual variabel gaya pengaturan kelas adalah kemampuan guru menetapkan kontrol, keteraturan, membangun interaksi yang positif, sertamendapatkan sikap kooperatif siswa di dalam kelas. Definisi operasional dari variabel gaya pengatuan kelas adalah semakin tinggi skor yang ditunjukkan oleh skala ini menggambarkan semakin tinggi kontrol dan keterlibatan interaksi yang positif guru di dalam kelas. Dimensi disiplin memiliki contoh butir positif: Saya menuntut sikap tertib di dalam kelas. Sedangkan contoh butir negatif adalah: Siswa masih terlalu kecil untuk menerima hukuman. Contoh butir positif untuk dimensi keterlibatan guru adalah: Saya menghargai ide dan pendapat siswa saya. Sedangkan contoh butir negatif adalah: Seringkali ide ataupun pendapat siswa tidak dapat saya aplikasikan dalam kegiatan belajar. Proses uji validitas dan reliabilitas secara lebih detil disajikan dalam tabel 3.1.

Tabel 3.1

Ringkasan Uji Validitas

\begin{tabular}{|c|c|c|c|c|c|c|c|}
\hline \multirow[b]{2}{*}{ No } & \multirow[b]{2}{*}{ Alat Ukur } & \multirow[b]{2}{*}{ Dimensi } & \multicolumn{2}{|c|}{ Sebelum Uji Coba } & \multicolumn{2}{|c|}{ Sesudah Uji Coba } & \multirow[b]{2}{*}{$\begin{array}{c}\text { Cronbach } \\
\text { Alpha }\end{array}$} \\
\hline & & & $\begin{array}{c}\text { Item } \\
\text { Positif }\end{array}$ & $\begin{array}{c}\text { Item } \\
\text { Negatif }\end{array}$ & $\begin{array}{c}\text { Item } \\
\text { Positif }\end{array}$ & $\begin{array}{c}\text { Item } \\
\text { Negatif }\end{array}$ & \\
\hline 1 & $\begin{array}{l}\text { Self- } \\
\text { efficacy }\end{array}$ & - & 26 & - & 23 & - & .956 \\
\hline \multirow{2}{*}{2} & \multirow{2}{*}{ Empati } & Kognitif & 13 & 14 & 9 & 2 & .903 \\
\hline & & Afektif & 9 & 8 & 6 & 3 & .854 \\
\hline \multirow[b]{2}{*}{3} & Gaya & Disiplin & 24 & 21 & 10 & 12 & .941 \\
\hline & $\begin{array}{l}\text { Pengaturan } \\
\text { Kelas }\end{array}$ & $\begin{array}{c}\text { Keterlibatan } \\
\text { Guru }\end{array}$ & 18 & 13 & 11 & 2 & .935 \\
\hline
\end{tabular}




\section{HASIL DAN PEMBAHASAN}

\section{Gambaran Variabel Penelitian}

Gambaran variabel-variabel dalam penelitian ini, yakni empati, self-efficacy dan gaya pengaturan kelas didapatkan dengan melakukan analisis descriptive statistic. Nilai rata-rata empati yang dimiliki guru lebih tinggi dibandingkan dengan nilai titik tengah alat ukur, yaitu 2.5. Artinya, guru merasa bahwa dirinya mampu memahami alur berpikir siswa, menginterpretasikan perasaan siswa melalui ekspresi maupun perilakunya, serta menghayati apa yang dirasakan oleh siswa. Nilai rata-rata self-efficacy yang dimiliki karyawan lebih tinggi dibandingkan dengan nilai titik tengah alat ukur, yaitu 2.5. Artinya, guru merasa bahwa dirinya mampu menjalankan tugas untuk mengendalikan perilaku agresif siswa di dalam kelas. Nilai rata-rata gaya pengaturan kelas yang dimiliki guru lebih tinggi dibandingkan dengan nilai titik tengah alat ukur, yaitu 2.5. Artinya, guru memiliki kemampuan untuk menerapkan kontrol yang tegas dan konsisten di dalam kelas, serta membangun keterlibatan yang tinggi dengan siswa. Penjelasan lebih lanjut dapat dilihat pada tabel 3.2 di bawah ini.

Tabel 3.2

\begin{tabular}{lcc}
\multicolumn{1}{c}{ Variabel } & Mean & Std. Dev \\
\hline Self-efficacy & 3.28 & 9.493 \\
Empati & 3.02 & 5.682 \\
Gaya Pengaturan Kelas & 2.81 & 6.534 \\
\hline
\end{tabular}

\section{Gambaran Data Demografi}

Gambaran data demografis partisipan akan dijelaskan satu per satu oleh peneliti, yaitu berdasarkan jenis kelamin, usia, status pendidikan terakhir, status kepegawaian, jenjang yang diajar dan lama mengajar. Dilihat dari jenis kelamin partisipan perempuan sebanyak 123 orang (99.2\%). Sisanya adalah partisipan laki-laki sebanyak 1 orang (0.8\%). Dilihat dari usia, partisipan terbanyak berusia antara 21 tahun sampai 40 tahun sebanak 98 orang (79\%). Diikuti oleh partisipan berusia antara 41 sampai 65 tahun sebanyak 25 orang (20.2\%). Terakhir partisipan berusia antara 11 sampai 20 tahun sebanyak 1 orang (0.8\%).Dilihat dari status pendidikan terakhir partisipan penelitian, maka mayoritas tingkat pendidikan partisipan adalah S1 sebanyak 83 orang (66.9\%), kemudian diikuti dengan tingkat pendidikan di bawah S1 sebanyak 32 orang (25.8\%), serta tingkat pendidikan di atas S1 sebanyak 9 orang (7.3\%).Dilihat dari status kepegawaian, terdapat 95 orang partisipan yang memiliki status kepegawaian tetap (76.6\%) dan sisanya terdapat 29 orang partisipan dengan status kepegawaian honorer (23.4\%).Dilihat dari jenjang pendidikan yang diajar, maka paling banyak partisipan mengajar jenjang TK yaitu 79 orang (63.7\%), diikuti dengan partisipan yang mengajar jenjang preschool sebanyak 41 orang $(33.1 \%)$ serta 4 orang partisipan yang mengajar sekaligus pada jenjang TK dan preschool (3.2\%).Dilihat dari lama mengajar, mayoritas partisipan memiliki pengalaman mengajar pada rentang $2-4$ tahun sebanyak 33 orang (26.6\%), diikuti dengan partisipan yang memiliki pengalaman mengajar pada rentang di atas 10 tahun sebanyak 30 orang (24.4\%). Lebih lanjut terdapat 25 partisipan yang memiliki pengalaman mengajar pada rentang $5-7$ tahun (20.2\%), sebanyak 20 orang partisipan yang memiliki pengalaman mengajar pada rentang $8-10$ tahun $(16.1 \%)$ dan 16 orang yang memiliki pengalaman mengajar pada rentang $0-1$ tahun $(12.9 \%)$.

\section{Uji Hipotesis}

Untuk mengevaluasi seberapa banyak peran varians empati dan self-efficacy terhadap varians gaya pengaturan kelas, peneliti menggunakan uji regresi berganda (multiple regression) dengan 
total skor gaya pengaturan kelas sebagai dependent variable. Dari uji hipotesis diperoleh hasil bahwa empati dan self-efficacy berperan terhadap gaya pengaturan kelas sebesar 17,50\%, dengan nilai signifikansi $0.00<0.05$. Maka dapat disimpulkan ada peran empati dan self-efficacy terhadap gaya pengaturan kelas. Penjelasan lebih detil tergambar pada tabel 3.3

Tabel 3.3

Hasil Uji Regresi Berganda

\begin{tabular}{cccc}
\hline \multicolumn{5}{c}{ Model Summary } \\
\hline Model & $\mathrm{R}$ & R Square & Adjusted R Square \\
\hline 1 & $.434^{\mathrm{a}}$ & .188 & .175 \\
\hline \multicolumn{5}{c}{} \\
\hline \multicolumn{5}{c}{ Model } & ANOVA $^{\mathrm{a}}$ & $\mathrm{S}$ \\
\hline \multicolumn{5}{c}{$\begin{array}{l}\text { Regression } \\
\text { Residual } \\
\text { Total }\end{array}$} \\
\hline
\end{tabular}

Dari data empati yang dimiliki ditemukan pula perbedaan yang signifikan antara gaya pengaturan kelas dari partisipan yang memiliki tingkat empati tinggi dengan partisipan yang memiliki tingkat empati rendah. Lebih detil dapat dilihat pada tabel 3.4.

Tabel 3.4

Hasil Uji Beda Empati dengan Gaya Pengaturan Kelas

\begin{tabular}{ccc} 
Empati & \multicolumn{2}{c}{ Gaya Pengaturan Kelas } \\
$\mathrm{t}$ & $\mathrm{P}$ \\
\hline & -4.333 & 0.000 \\
\hline
\end{tabular}

Demikian pula terdapat perbedaan yang signifikan antara gaya pengaturan kelas dari partisipan yang memiliki tingkat self-efficacy tinggi dan partisipan yang memiliki self-efficacy rendah. Penjelasan lebih detil dapat dilihat pada tabel 3.5.

Tabel 3.5

Hasil Uji Beda Self-efficacy dengan Gaya Pengaturan Kelas

\begin{tabular}{ccc} 
Self-efficacy & \multicolumn{2}{c}{ Gaya Pengaturan Kelas } \\
$\mathrm{t}$ & $\mathrm{p}$ \\
\hline-4.387 & 0.000 \\
\hline
\end{tabular}

\section{Analisis Tambahan}

Penelitian ini juga menguji peran empati dan self-efficacy terhadap dimensi disiplin dan dimensi keterlibatan guru. Hasil uji regresi berganda menunjukkan bahwa empati dan self-efficacy memiliki peran sebesar 3,9\% terhadap disiplin dengan nilai signifikansi $0.033<0.05$. Dari kedua variabel tersebut, hanya variabel self-efficacy yang berperan signifikan terhadap disiplin, dengan nilai signifikansi sebesar $0.012<0.05$.

Demikian pula empati dan self-efficacy memiliki peran sebesar $13 \%$ terhadap keterlibatan guru dengan nilai signifikansi $0.00<0.05$. Dari kedua variabel tersebut didapatkan pula hasil bahwa 
hanya variabel empati yang memiliki peran signifikan terhadap keterlibatan guru, dengan nilai signifikansi $0.00<0.05$.

Penelitian ini juga menguji apakah terdapat perbedaan empati dan self-efficacy yang dimiliki oeh guru bila dilihat dari lama pengalaman mengajar. Hasil pengolahan data menunjukkan bahwa terdapat perbedaan empati dan self-efficacy antara guru dengan lama pengalaman mengajar yang berbeda-beda. Penjelasan lebih lengkap dapat dilihat pada tabel 3.6

Tabel 3.6

Hasil Uji Beda Empati dan Self-Efficacy Dilihat dari Lama Mengajar

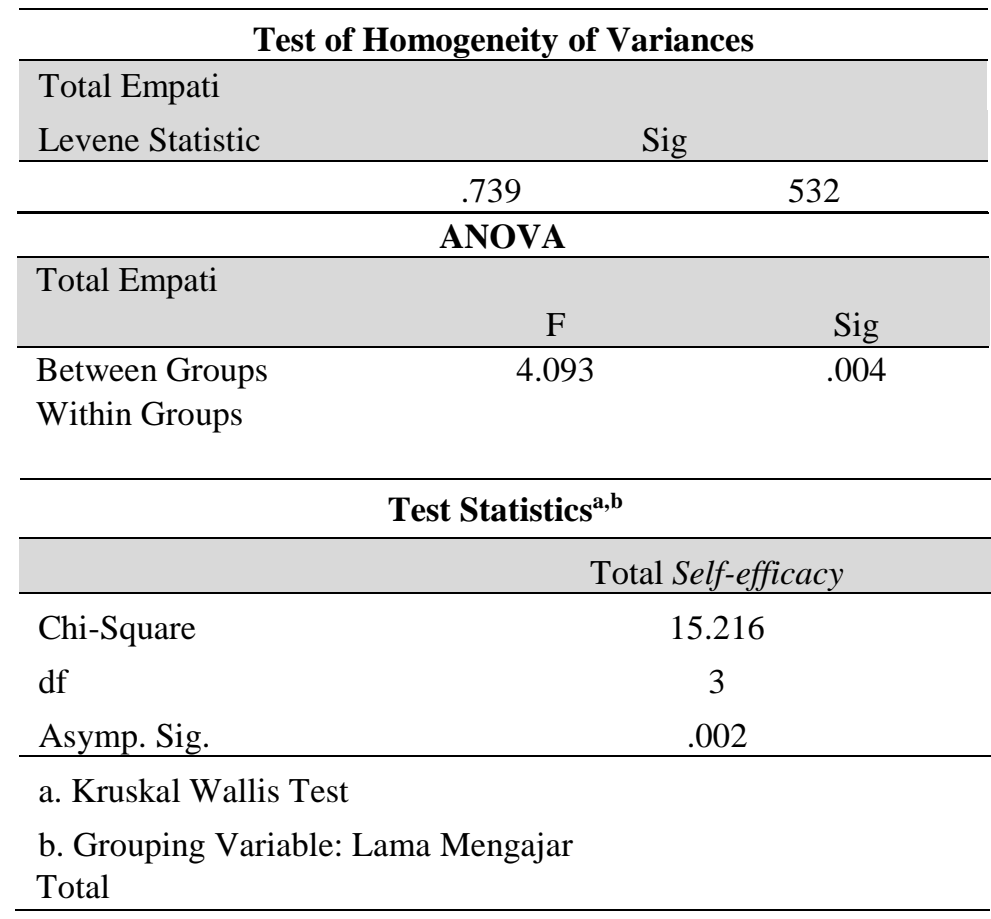

Penelitian ini merupakan temuan baru yang melengkapi keterbatasan yang ada pada penelitian sebelumnya (Yoon, Sulkowski \& Bauman, 2014) yang hanya mengaitkan empati dengan respon hipotesis terhadap fenomena bullying. Demikian pula Yoon dan Bauman dalam penelitian lanjutannya menjelaskan bahwa respon guru memang perlu dipahami dalam konteks classroom management (pengaturan kelas). Untuk itu hasil yang diperoleh untuk peran empati dan selfefficacy terhadap gaya pengaturan kelas memberikan kontribusi terhadap literatur classroom management yang belum terjabarkan pada penelitian sebelumnya.

Penelitian ini juga menemukan bahwa self-efficacy memiliki peran yang signifikan terhadap dimensi disiplin pada gaya pengaturan kelas, dengan nilai signifikansi $0.033<0.05$. Di lain pihak empati ditemukan tidak memiliki peran signifikan terhadap dimensi disiplin. Hal ini berarti bahwa semakin tinggi keyakinan guru akan kemampuan dirinya dalam menerapkan kontrol di dalam kelas dapat memprediksi kemampuan guru menerapkan kontrol dan pengaturan untuk menyelesaikan masalah ketertiban di dalam kelas. Temuan ini sejalan dengan teori yang mengatakan bahwa self-efficacy guru berkaitan erat dengan penilaian guru terhadap kemampuannya dalam menghadapi tugas-tugas guru yang cukup berat (Schunk, dalam Santrock, 2010). Tugas untuk menerapkan disiplin dan kontrol pada anak usia dini dalam penelitian ini diasumsikan sebagai tugas yang secara spesifik cukup berat untuk dijalankan oleh mereka. 
Lebih lanjut ditemukan bahwa empati memiliki peran yang signifikan terhadap dimensi keterlibatan guru, dengan nilai signifikansi $0.00<0.05$, sedangkan self-efficacy tidak memiliki peran yang signifikan terhadap dimensi keterlibatan guru. Maka dapat disimpulkan bahwa kemampuan guru untuk memahami pemikiran siswa serta merasakan apa yang dirasakan oleh siswa dapat memprediksi kemampuan guru membangun interaksi yang positif dengan siswa dan mendapatkan sikap kooperatif dari mereka. Hal ini sejalan dengan teori yang mengatakan bahwa empati yang dimiliki oleh guru berkaitan dengan kemampuan guru berinteraksi dan berkomunikasi dengan siswanya dalam rangka untuk memahami pemikiran dan menghayati perasaan mereka (Cooper, dalam Murphy, Tubritt \& Norman, 2018; Goroshit \& Hen, 2016).

Adanya perbedaan empati dan self-efficacy terhadap gaya pengaturan kelas pun sejalan dengan teori bahwa guru yang memiliki empati lebih tinggi memiliki tingkat keberhasilan yang juga lebih besar dalam membangun komunikasi dengan siswa (Goroshit \& Hen, 2016). Begitu pula self-efficacy yang lebih tinggi mampu lebih baik dalam menetapkan langkah ataupun strategi yang perlu dilakukan dalam menyelesaikan tugas-tugasnya (Woolfolk, 2017).

Peneliti juga menemukan adanya perbedaan empati dan self-efficacy bila dilihat dari lama pengalaman mengajar. Hal ini merupakan temuan yang melengkapi penelitian yang dilakukan oleh Boulton (1997) yang membuktikan bahwa rentang pengalaman guru TK memiliki korelasi yang signifikan dengan respon guru terhadap fenomena bullying.

Keterbatasan dalam penelitian ini adalah pada jumlah partisipan, terkait dengan tingkat kesibukan partisipan yang cukup tinggi sehingga seringkali kurang bersedia turut serta dalam penelitian dengan cara mengisi kuesioner. Profesi guru TK yang masih didominasi oleh perempuan pun menyebabkan peneltian belum dapat mendapatkan perbandingkan berdasarkan jenis kelamin. Hal ini diprediksi karena adanya persepsi budaya di Indonesia yang masih mengasosiasikan tugas pendidikan anak usia dini secara ideal dilakukan oleh perempuan.

Keterbatasan lainnya adalah pada pengukuran yang hanya menggunakan satu metode saja, sehingga masih ada potensi bias, mengingat partisipan diminta untuk memberikan penilaian terhadap dirinya sendiri. Begitu pula sebesar $30.6 \%$ partisipan yang tidak mengisi pertanyaan mengenai contoh perilaku agresif yang pernah terjadi di dalam kelas dan tindakan apa yang dilakukan guru. Peneliti memiliki asumsi bahawa ada beberapa alasan yang mendasari, yakni kecenderungan guru TK kurang mampu mengenali adanya perilaku agresif yang ditampilkan siswa di dalam kelas, ada pula kemungkinan guru TK merasa khawatir jawabannya akan dinilai oleh peneliti.

Kurangnya fokus terhadap fenomena unjustified aggression dalam penelitian ini disebabkan oleh keterbatasan peneliti dalam mencari kasus unjustified aggression, terkait dengan masih minimnya pengetahuan dan pemahaman guru mengenai fenomena ini. Demikian pula ada kecenderungan sikap yang kurang terbuka dari guru maupun kepala sekolah saat peneliti menggali informasi mengenai perilaku agresif siswa di sekolah. Hal ini juga disebabkan oleh tingkat kesibukan guru yang tinggi serta keengganan yang cukup besar untuk membaca kuesioner sehingga guru menolak untuk berpartisipasi dalam penelitian ataupun sekedar melakukan wawancara singkat mengenai aktivitas di dalam kelas.

\section{KESIMPULAN DAN SARAN}

Hasil dari penelitian menunjukkan bahwa empati dan self-efficacy secara bersama-sama dapat memprediksi gaya pengaturan kelas sebesar 17,50\%, dengan nilai signifikansi $0.00<0.05(\mathrm{R}=$ 
0.188). Hal ini menjawab masalah penelitian bahwa ada peran empati dan self-efficacy guru TK terhadap gaya pengaturan kelas dalam konteks unjustified aggression.

Saran metodologis bagi penelitian berikutnya adalah dengan memperbanyak jumlah partisipan agar semakin mewakili populasi dan meningkatkan signifikansi dari hasil penelitian. Kerja sama dan rapport dengan pihak sekolah perlu dibangun secara bertahap sehingga dapat menjangkau partisipan lebih banyak lagi. Demikian pula dapat menggunakan beberapa metode pengambilan data untuk meminimalisasi potensi bias akibat subjektivitas partisipan dalam mengisi kuesioner. Peneliti juga berharap penelitian selanjutnya dapat menggali lebih dalam mengenai fenomena unjustified aggression yang terjadi di kalangan siswa TK maupun preschool sehingga dapat memperkaya literatur yang masih sangat minim mengenai unjustified aggresion.

\section{Ucapan Terima Kasih (Acknowledgement)}

Ucapan terima kasih disampaikan kepada berbagai pihak khususnya Kepala Sekolah, Guru, dan para siswa yang terlibat dalam penelitian ini.

\section{REFERENSI}

Arfiadi, Y. \& Hadi, MNS. (2006). Continuous bounded controller for active control of structures. Computers and Structures, 84, 798-807.

Boulton, M. (1997). Teachers' view on bullying: Definitions, attitudes and ability to cope. British Journal of Educational Psychology, 67(2), 223-233.

Cummings, E. M., Iannotti, R. J., Waxler, C. Z. (1989). Aggression between peers in early childhood: Individul continuity and developmental change. Child Development, 60(4), 887-895.

Goroshit, M., Hen, M. (2016). Teachers' empathy: Can it be predicted by self-efficacy? Teachers and Teaching: Theory and Practice, 22(7), 805-818.

Gregus, S. J., Rodriguez, J. H., Pastrana, F. A., Craig, J. T., McQuillin, S. D., Cavell, T. A. (2017). Teacher self-efficacy and intentions to use antibullying practices as predictors of children's peer victimization. School Psychology Review, 46(3), 304-319.

Ireland, J. L., Birch, P., Ireland, C. A. (2018). The routledge international handbook of human aggression: Current issues and perspectives. New York: Routledge.

Kirves, L., \&Sajaniemi, N. (2012). Bullying in early educational settings. Early Child Development and Care, 182(3-4), 383-400.

Lee, J. C., Syawal, M., Adzrieman, N. (2016). Teachers' self-efficacy in dealing with bullying among secondary school students in Malaysia. Journal of Education and Social Sciences, 4, 48-56.

Loeber, R., Hay, D. (1997). Key issues in the development of aggression and violence from childhood to early adulthood. Annual Review of Psychology, 48(1), 371-410.

Monks, C. P., Ruiz, R. O., Val E. T. (2002). Unjustified aggression in preschool. Aggressive Behavior, 28(6), 458-476.

Murphy, H., Tubritt, J., Norman, J. O. (2018). The role of empathy in preparing teachers to tackle bullying. Journal of New Approaches in Educational Research, 7(1), 17-23.

Reebye, P. (2005). Aggression during early years - Infancy and preschool. The Canadian Child and Adolescent Psychiatry Review, 14(1), 16-20.

Santrock, J. W. (2010). Child Development. Mcgraw-hill College.

Sarraf, M. \& Bruneau, M. (1998). "Ductile sismic retrofit of steel deck-truss bridges, II: Design applications". J. Struct. Engrg., 124(11), 1263-1271. 
Vlachou, M., Andreou, E., Botsoglou, K., \&Didaskalou, E. (2011). Bully/victim problems among preschool children: A reviewof current research evidence. Educational Psychology Review, 23(3), 329-358.

Vlachou, M., Botsoglou, K., \&Andreou, E. (2014). Bullying/victimization in preschool children. Conference paper. Diaksesdari doi:10.13140/2.1.5086.1764

Woolfolk, A. (2007). Educational psychology (10 ${ }^{\text {th }}$ Ed.). USA: Pearson Education.

Yoon, J., \& Bauman, S. (2014). Teachers: A critical but overlooked component of bullying prevention and intervention. Theory Into Practice, 53, 308-314.

Yoon, J. (2004). Predicting Teacher Interventions in Bullying Situations. Education and Treatment of Children, 27(1), 37-45.

Yoon, J., \& Kerber, K. (2003). Bullying: Elementary teachers' attitudes and intervention strategies. Research in Education, 69, 27-35.

Yoon, J., Sulkowski, M. L., \& Bauman, S. A. (2014). Teachers' responses to bullying incidents: Effect of teacher characteristics and context. Journal of School Violence, 15(1), 91-113. 